\title{
Relation between the craniocervical cephalometric analysis and class I, II and III skeletic patterns in young subjects
}

\section{Relação entre a análise cefalométrica crânio-cervical e padrões esqueléticos classes I, II e III em indivíduos jovens}

\author{
Luciano Pereira ROSA \\ Adjunct Professor - Federal University of Bahia - Vitória da Conquista - BA - Brazil. \\ Luiz César de MORAES \\ Titular Professor - UNESP - Univ Estadual Paulista - São José dos Campos - SP - Brazil.
}

\begin{abstract}
A BSTR ACT
The skull posture on the spine is an important factor for the diagnosis of craniomandibulars functional disorders in children, as well as in adults. Alterations in biomechanics may be evidenced in common x-rays. The aim of this study was to relate findings of craniocervical analysis with skeletal pattern Class I, II, III in individuals from 7 to 12 years old. X-rays of 92 individuals were taken by NHP method and digitalized for computerized analysis of skeletic patterns and craniocervical analysis. Descriptive analysis was used to relate craniocervical analysis values with the type of skeletal pattern presented by individuals. For skeletal pattern Class I, II and III, nasopharyngeal soft tissue percentage and oropharyngeal soft tissue linear quantity were above normality value; nasopharyngeal cervical plot was normal and hyoid triangle was positive for the majority of the individuals. The angular relationship between skull and cervical spine show values lower than those considered normal for skeletal pattern class I and II. It was concluded that in the majority of the individuals with skeletal pattern Class I, II and III had high values of airway blockage, head posterior rotation, nasopharyngeal cervical plot with normal values and positive hyoid triangle.
\end{abstract}

K EYWORDS

Skull; posture; radiology; cephalometry.

INTRODUCT ION

Recent research indicates consistent association between dento skeletal morphology and individual variation in head posture, showing how biomechanical principles of spine and neck are of special interest in Orthodontics and Dentomaxilofacial Orthopedics [13]. Postural orthostatic skull stability on the cervical spine is an important factor in the diagnosis of craniomandibular functional disorders both in children and in adults. For many years this factor was not included in a protocol for differential diagnosis, although biomechanical changes of both hard tissue and soft tissue are usually evident on radiographs $[4,5]$.

The strongest evidence of the relationship between head posture and changes in occlusion was described by Rocabado et al. [6] as an association between Class II skeletal pattern and head posture. This relationship can be explained by anatomical and biomechanical interactions. Accordingto Solow and Sonnesen[7], individualswith Class II skeletal pattern have smaller cranio-cervical angles and cervico-horizontal angles greater than individuals with different types of skeletal patterns.

The evaluation of the posture can be performed by clinical or radiographic methods. The technique described by Rocabado [4] assesses skull stability on cervical spine through the analysis of three parameters: measurement of posteroinferior angle formed by McGregor plan and odontoid plan, $\mathrm{C} 0-\mathrm{C} 1$ space and hyoid triangle $[8,9]$.

The aim of this study was to relate the findings of craniocervical analysis with the skeletal pattern Class I, II and III in individuals with chronological age from 7 to 12 years. 


\section{Material and Methods}

Ninety two lateral cephalometric x-rays obtained from individuals from 7 to 12 years indicated for orthodontic/orthopedic treatment in São Paulo State University Dental Clinic. This study was approved by the Ethic Committee for Researches with Humans in the same institution, with protocol number 087/2005$\mathrm{PH} / \mathrm{CEP}$.

\section{Obtention of lateral cephalometric X-rays}

Lateral cephalometric X-rays were performed in the Discipline of Oral Radiology at São Paulo State University. All radiographs were obtained by only one operator using a X-Ray FUNK ORBITAL X-15 (Funk, Ribeirão Preto, São Paulo, Brazil) operating with $80 \mathrm{kVp}, 10 \mathrm{~mA}$, 0,4 seconds of exposition, $1,51 \mathrm{~m}$ focal distance, with individuals in natural head position (NHP) in all exposures.

The lateral cephalometric X-rays were digitalized in HPSCANJET 6100C scanner (Hewlett-Packard, Colorado, USA) with transparency adapter HPC $62616100 \mathrm{C}$ (HewlettPackard, Colorado, USA) and their HP DeskScan II MICROSOFT WINDOWS VERSION software (Hewlett-Packard, Colorado, USA) to image capture. The images were captured with "Sharp Black and White Photo" standard, keeping brightness and contrast values of 120 and 140 , respectively, with a resolution of 75 dpi and $100 \%$ scale capture.

\section{Sample division}

The 92 individuals were divided in three groups according to skeletal pattern Class I, II or III by ANB angle and Wits analysis using the software RADIOCEF - an integrant part of the package RADIOCEF STUDIO 2 (Radiomemory, Belo Horizonte, Minas Gerais, Brazil). This analysis was performed twice at a thirty-day interval aiming intraobserver error evaluation.

\section{Tracement and cranio-cervical cephalometric analysis}

Craniocervical analisys (Chart 1 and Figure 1) was also performed by using the software cited above, being this analysis done twice at a thirty-day interval aiming intra-observer error evaluation.

\section{Chart 1 - Description of the points and CEPHALOMETRIC PLANS USED IN CRANIO-CERVICAL ANALYSIS}

\begin{tabular}{|c|c|}
\hline $\begin{array}{l}\text { POINTS E } \\
\text { PLANS }\end{array}$ & DESCRIPTION \\
\hline Cli (Clivus) & $\begin{array}{l}\text { Lower third of the "clivus". Randomly marked } \\
\text { at } 1 \mathrm{~cm} \text { of the inferior extremity }\end{array}$ \\
\hline Od & The most superior point of the Axis tooth \\
\hline Enp & The most posterior point of the hard palate \\
\hline PTVR & $\begin{array}{l}\text { The most posterior portion of the } \\
\text { pterygomaxillare fossa image }\end{array}$ \\
\hline $\mathrm{H}$ & $\begin{array}{l}\text { The most superior and anterior point of the } \\
\text { hyoid bone }\end{array}$ \\
\hline $\mathrm{C} 2$ & The most anteroinferior point of the Axis tooth \\
\hline C3ai & $\begin{array}{l}\text { The anteroinferior angle of the vertebral body } \\
\text { at the third cervical vertebra }\end{array}$ \\
\hline Rgn & The most protrusive point of retrognation \\
\hline $\mathrm{BC}$ & The most inferior point of the cranial base \\
\hline PPM & $\begin{array}{l}\text { The most inferior point of the soft palate } \\
\text { image }\end{array}$ \\
\hline At & The most anterior point of the Atlas body \\
\hline Cia & $\begin{array}{l}\text { The most superoposterior point of the Atlas } \\
\text { arch }\end{array}$ \\
\hline TMN & $\begin{array}{l}\text { Point of the anterior rim of the } \\
\text { nasopharyngeal tissue marked above }\end{array}$ \\
\hline PFS & $\begin{array}{l}\text { Point located in the posterior pharyngeal wall } \\
\text { between the points Cli and Enp }\end{array}$ \\
\hline PFM & $\begin{array}{l}\text { Point located in the posterior pharyngeal wall } \\
\text { between the points At and Enp }\end{array}$ \\
\hline PFI & $\begin{array}{l}\text { Point located in the posterior pharyngeal wall } \\
\text { between the points C2 and PPM }\end{array}$ \\
\hline $\mathrm{AO}$ & $\begin{array}{l}\text { Distance between the occipital base and the } \\
\text { posterior Atlas arch }\end{array}$ \\
\hline $\mathrm{HI}$ & $\begin{array}{l}\text { Perpendicular line from the plan C3ai-Rgn to } \\
\text { the point } \mathrm{H}\end{array}$ \\
\hline $\begin{array}{c}\text { PMG (Mc } \\
\text { Gregor Plane) }\end{array}$ & Trace from Enp to the occipital base \\
\hline OP & Odontoid Plan \\
\hline $\begin{array}{l}\text { PTV } \\
\text { (Pterygoid } \\
\text { plan) }\end{array}$ & $\begin{array}{l}\text { Perpendicular line to Frankfurt plan that } \\
\text { passes by the PTVR point (more posterior } \\
\text { point of the pterigomaxillare image) }\end{array}$ \\
\hline
\end{tabular}



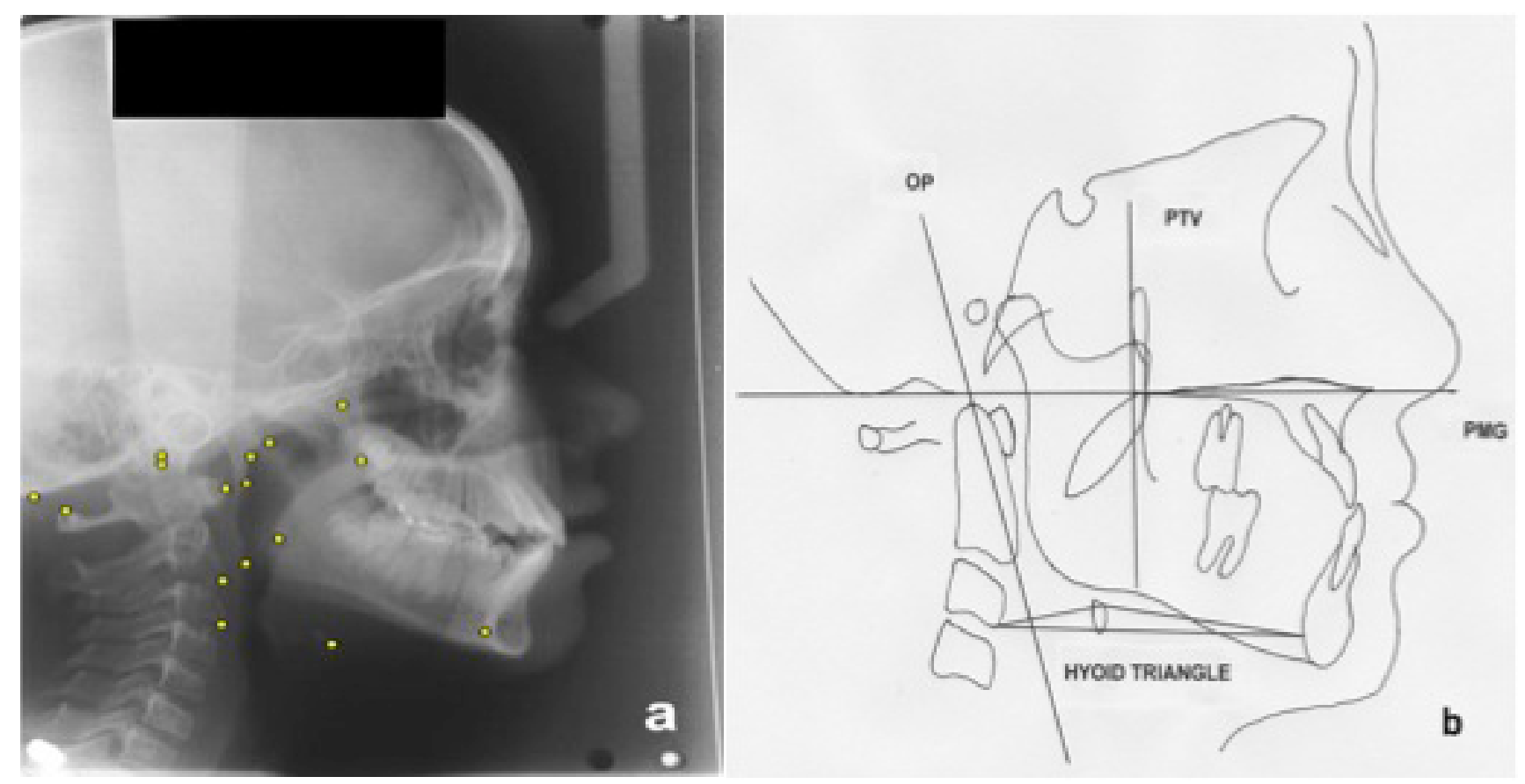

FIGURE 1 - Cranio-cervical cephalogram.

\section{Statistical Analysis}

Intra-observer error of cranial-cervical, ANB and Wits analysis was performed by using regression equation analysis. The descriptive analysis was used to relate cranial-cervical values analysis with skeletal pattern (Class I, II and III) presented by individuals.

\section{Results}

\section{Intra-observer error analysis}

The results obtained with determination values of regression analysis can be observed in Table 1 .

\section{TABLe 1 - Determination Values of REgRession ANALYSIS FOR the SKELETAL PATTERn GROUPS}

\begin{tabular}{l|c|c|c}
\hline & Class I & Class II & Class III \\
\hline ANB & 0,78 & 0,86 & 0,81 \\
\hline WITS & 0,82 & 0,83 & 0,79 \\
\hline NASOPH & 0,9 & 0,87 & 0,79 \\
\hline OROPH & 0,88 & 0,76 & 0,91 \\
\hline LARING & 0,91 & 0,93 & 0,83 \\
\hline TNFC & 0,76 & 0,74 & 0,78 \\
\hline AO & 0,79 & 0,86 & 0,96 \\
\hline PMG/OP & 0,92 & 0,86 & 0,81 \\
\hline
\end{tabular}

ANB = angle between the line N-A; WITS= linear distance between AO and BO; NASOPH= percentage of soft tissue of anteroposterior nasopharyngeal region; $\mathrm{OROPH}=$ quantity, in linear millimeters, of oropharyngeal soft tissue; LARING= quantity, in linear millimeters, of laryngopharyngeal soft tissue; TNFC= nasopharingeal-cervical plot; $\mathrm{AO}=$ distance between the occipital base and posterior Atlas arch; PMG/OP= angular relationship between the skull and cervical spine measured through an angle formed by Mc Gregor and odontoid plan; Hyoid Triangle= linear distance measured by a perpendicular line from the $\mathrm{H}$ point (hyoid) up to the Plan C3ai-Rgn. 


\section{Skeletal Pattern Class I}

Results obtained through descriptive analysis of the data from a group of individuals with skeletal pattern Class I are shown in Table 2.

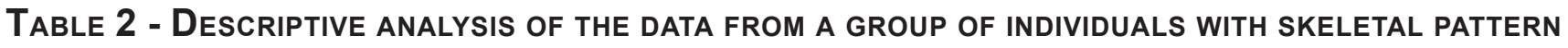
CLASS I

\begin{tabular}{l|c|c|c|c|c|c|c}
\hline $\begin{array}{c}\text { Variable } \\
\text { (Normal values) }\end{array}$ & N & Mean & $\begin{array}{c}\text { St } \\
\text { Dev }\end{array}$ & $\begin{array}{c}\text { Min } \\
\text { Value }\end{array}$ & $\begin{array}{c}\text { Max } \\
\text { Value }\end{array}$ & Q1 & Q3 \\
\hline ANB & 47 & 2,66 & 1,26 & 0,00 & 4,00 & 1,77 & 3,93 \\
\hline WITS & 47 & $-0,90$ & 1,27 & $-3,00$ & 1,67 & $-2,00$ & 0,28 \\
\hline NASOPH $(>40 \%)$ & 47 & 56,82 & 10,87 & 31,60 & 83,70 & 48,80 & 64,20 \\
\hline OROPH $(\leq 4 \mathrm{~mm})$ & 47 & 9,09 & 5,34 & 3,21 & 31,90 & 5,09 & 11,85 \\
\hline LARING $(>4 \mathrm{~mm})$ & 47 & 4,99 & 1,74 & 1,22 & 10,05 & 3,79 & 6,03 \\
\hline TNFC $>$ (>mm) & 47 & 6,84 & 4,34 & 0,35 & 21,73 & 3,80 & 8,43 \\
\hline AO (4-9mm) & 47 & 8,22 & 3,14 & 2,91 & 17,35 & 5,79 & 10,31 \\
\hline PMG/OP (96-106 $\left.{ }^{\circ}\right)$ & 47 & 75,86 & 9,28 & 59,90 & 102,97 & 69,28 & 81,67 \\
\hline Hyoid Triangle & 47 & 2,25 & 3,79 & $-5,70$ & 14,41 & $-0,05$ & 4,40 \\
(positive values) & & & & & & &
\end{tabular}

Legend: see Table 1

\section{Skeletal Pattern Class II}

Results obtained through descriptive analysis of the data from a group of individuals with skeletal pattern Class II are shown in Table 3.

TABle 3 - Descriptive ANALYSIS OF THE DATA FROM A GROUP OF INDIVIDUALS WITH SKELETAL PATTERN Class II

\begin{tabular}{|c|c|c|c|c|c|c|c|}
\hline $\begin{array}{c}\text { Variable } \\
\text { (Normal values) }\end{array}$ & $\mathbf{N}$ & Mean & $\begin{array}{c}\text { St } \\
\text { Dev }\end{array}$ & Min Value & Max Value & Q1 & Q3 \\
\hline ANB & 35 & 6,80 & 2,28 & 2,03 & 12,59 & 5,12 & 7,73 \\
\hline WITS & 35 & 5,22 & 2,62 & 1,05 & 11,89 & 2,97 & 6,77 \\
\hline NASOPH (> 40\%) & 35 & 50,46 & 14,07 & 25,90 & 86,00 & 40,90 & 60,20 \\
\hline OROPH $(\leq 4 \mathrm{~mm})$ & 35 & 8,75 & 4,78 & 2,27 & 24,69 & 5,43 & 11,74 \\
\hline LARING (> 4mm) & 35 & 5,64 & 2,21 & 0,34 & 9,37 & 4,40 & 7,05 \\
\hline TNFC $(>5 \mathrm{~mm})$ & 35 & 8,47 & 5,15 & $-0,76$ & 22,41 & 4,34 & 11,73 \\
\hline AO $(4-9 \mathrm{~mm})$ & 35 & 9,53 & 4,34 & 2,63 & 22,94 & 7,37 & 10,74 \\
\hline PMG/OP $\left(96-106^{\circ}\right)$ & 35 & 73,75 & 10,57 & 55,90 & 105,54 & 65,30 & 80,61 \\
\hline $\begin{array}{l}\text { Hyoid Triangle } \\
\text { (positive values) }\end{array}$ & 35 & 3,66 & 5,61 & $-11,49$ & 13,60 & $-0,30$ & 8,02 \\
\hline
\end{tabular}

Legend: see Table 1

\section{Skeletal Pattern Class III}

Results obtained through descriptive analysis of the data from group of individuals with skeletal pattern Class III are shown in Table 4. 
Table 4 - Descriptive analysis of the data from group of individuals with skeletal pattern Class III

\begin{tabular}{|c|c|c|c|c|c|c|c|}
\hline $\begin{array}{c}\text { Variable } \\
\text { (Normal values) }\end{array}$ & $\mathbf{N}$ & Mean & $\begin{array}{c}\text { St } \\
\text { Dev }\end{array}$ & Min Value & Max Value & Q1 & Q3 \\
\hline ANB & 10 & $-0,91$ & 0,48 & $-1,68$ & $-0,19$ & $-1,30$ & $-0,58$ \\
\hline WITS & 10 & $-6,93$ & 2,41 & $-11,52$ & $-2,84$ & $-7,85$ & $-5,32$ \\
\hline NASOPH (> 40\%) & 10 & 46,97 & 14,29 & 22,80 & 68,00 & 34,42 & 58,68 \\
\hline OROPH $(\leq 4 \mathrm{~mm})$ & 10 & 5,77 & 1,86 & 2,91 & 8,86 & 4,54 & 7,25 \\
\hline LARING (> 4mm) & 10 & 6,17 & 1,20 & 4,72 & 8,18 & 5,08 & 7,21 \\
\hline TNFC (> 5mm) & 10 & 7,01 & 3,22 & 1,56 & 11,25 & 4,14 & 10,27 \\
\hline AO (4-9mm) & 10 & 6,45 & 2,27 & 2,51 & 9,77 & 5,00 & 8,45 \\
\hline PMG/OP $\left(96-106^{\circ}\right)$ & 10 & 79,14 & 6,86 & 71,53 & 93,10 & 74,13 & 84,75 \\
\hline $\begin{array}{l}\text { Hyoid Triangle } \\
\text { (positive values) }\end{array}$ & 10 & 1,68 & 5,06 & $-4,80$ & 8,49 & $-2,28$ & 7,33 \\
\hline
\end{tabular}

Legend: see Table 1

\section{Discussion}

Sagittal skeletal relation of maxilla and mandible is an important factor to be evaluated during orthodontic treatment. This relation is used to establish detailed guidelines of the treatment and its mechanic. From the orthodontist point of view, patient's facial profile is better described by the anteroposterior relationship of maxilla/mandible regarding to cranial anatomy [10].

Our findings showed that a hundred percent of the individuals present $\mathrm{PMG} / \mathrm{OP}$ angle with indicative values of head posterior rotation. Another measurement that is also used to define head rotation degree in relation to cervical spine is AO. The interpretation of this measurement not always coincides with interpretation performed by using angle PMG/OP. According to Rocabado [4], those measurements should be complementary. It was found that while the values of PMG/OP in all individuals of the sample showed posterior head rotation, the distance of $\mathrm{AO}$ in most of the individuals showed to be normal. Fuentes et al. [11], also observed contradiction in the results interpretation, which pointed that not necessarily those measurements are complementary.

Results related to head rotation differed from the ones obtained by Henríquez et al.[12], who demonstrated that $71 \%$ of the forty-five individuals of his sample showed posterior head rotation. For the distance between occipital base and posterior arch of the Atlas, it was verified that most of the individuals (that makes a total of 57 among skeletal patterns class I and III) had that measurement considered normal. Individuals with skeletal pattern Class II (a total of 35 individuals) had measurements compatible with anterior head rotation, not supporting Henríquez et al.
[12] research, which verified that $51 \%$ of his sample had values above $9 \mathrm{~mm}$, indicating anterior head rotation.

Rocabado et al. [9], Solow and Sonnesen [7], reported an association between skeletal pattern Class II and anterior head posture, that could be defined as an anterior cervical inclination combined with small or lower cranial-cervical angle in a three quarter degrees regarding to individuals without this skeletal pattern. Results obtained in this work are in accordance to these authors, because individuals with skeletal pattern Class I had 75,86o, Class III had $79,14^{\circ}$, Class II had 73,75 o of cranial-cervical angles, showing that individuals with skeletal pattern Class II had values of PMG/OP smaller than 2.11o when compared to the individuals with skeletal pattern Class I and 5.39o when compared to the individuals with skeletal pattern Class III.

Our results differed from the results obtained by Sandoval et al. [13] and Ferrario et al. [14], where it was observed that most of the individuals that presented skeletal pattern Class II showed tendency to posterior head rotation of the skull. All the individuals with skeletal pattern Class II of the sampled in this work presented PMG/OP angles smaller than the ones considered normal, indicating posterior cranial rotation in relation to cervical spine. Ferrario et al. [14], also evaluated individual with skeletal pattern Class I verifying that $64 \%$ had anterior rotation and only $36 \%$ had posterior rotation. Our findings demonstrated that all individuals with skeletal pattern Class I presented posterior head rotation, which are not in accordance to the results obtained by the authors cited above. Gadotti et al. [15], found anterior head rotation in most of individuals with skeletal pattern Class II, not 
in agreement with our results.

Regarding the position of hyoid and head, Muto and Kanazawa [16], reported that the hyoid bone alters its position with the change of head position. Individuals with skeletal pattern Class III showed posterior head rotation with the hyoid bone moving to upper position. Our results revealed that individuals with skeletal pattern Class III were the ones who presented the highest posterior head rotation $\left(79,14^{\circ}\right)$ and also had the smallest distance of the hyoid bone with line C3ai-Rgn. Results were in agreement with the ones obtained by authors cited before. Gale et al. [17], reported that for the approximation of hyoid bone to mandible in individuals with skeletal pattern Class III just $28.3 \%$ of these had posterior head rotation, which is not in agreement with our results, due to all the individuals presented posterior head rotation.

Hyoid bone position alteration closer to mandible in the individual with skeletal pattern Class III can be explained due to the strain of the hyoid muscles with balance activity of the strength of the supra and infra hyoid muscles. This fact is important, once it has been emphasized in recent years that dysfunctional factors that affect hyoid system produced not only local - but also general - effects $[4,8,18]$. Eggensperger et al. [19] and Cuccia et al. [20] also observed that changes in mandibular position can affect the position of the hyoid bone. With mandibular recoil the hyoid occupied a most inferior position. Our results are different from these results, because in individuals of the sample, that had skeletal pattern Class III, the hyoid occupied an upper position regarding the ones of Class II and I. The authors also verified that with mandibular recoil there was a decreasing of nasopharyngeal space. This was only observed in naso and oro-pharyngeal air spaces, once in laryngopharyngeal there was an increase of the dimensions when compared to individual with skeletal pattern Class I and II.

Hyoid bone position is also of a clinic importance because it influences in the maintenance of airway dimensions [8,18,21]. Allhaija and Al-Khateeb [22] reported that individuals with skeletal pattern Class I, II and III showed positive hyoid triangle (with a small difference between skeletal pattern Class II and III, once the ones with Class II showed the hyoid more slightly superior than the ones with Class III). Results obtained showed that individuals with skeletal pattern Class II presented a hyoid bone in a more inferior position than these individual with skeletal pattern Class III. The authors also verified that anteroposterior dimensions of the pharyngeal air space were not affected by ANB angle changes. In this work there were differences in the NASOPH values among skeletal patterns classes $(56,82 \%, 50,46 \%$ e $46,97 \%$, corresponding to skeletal patterns Class I, II e III, respectively), pointing out that individuals with skeletal pattern Class I and II had a smaller nasopharingeal space than normal. The ones of Class III had that measurement considered normal.

For all the mensurations performed in oropharynx and laryngopharingeal space, individuals of three skeletal pattern types showed indicative values of space decreasing. However, individuals of skeletal pattern of Class II and III had higher values for LARING. Those results are in accordance to the ones obtained by Kerr [23] and Wang et al. [21], that observed a general tendency of the individual with skeletal Class II to have an increase of the nasopharyngeal space when compared to the ones of skeletal pattern Class I.

Yamaoka et al. [24], found values of oropharyngeal air space higher for individual with skeletal pattern Class III than for Class II, and did not find differences in dimensions of the laryngopharyngeal space between the Classes II and III. This is in agreement with our work that individuals with skeletal pattern Class III also had higher values for OROPH. Regarding laryngopharyngeal space, results here presented are also similar to the author cited above, because there was a small difference in the values obtained to individuals with skeletal pattern Class II and III.

Similar results that ones of Battagel et al. [25], were found by us when it was verified that anterior positioning of the mandible was related to the approach of the hyoid bone and with an increase of oropharynx dimensions.

\section{Conclusions}

With the results obtained with sample analysis and methodology used in this work, we conclude that individuals with skeletal pattern Class I, II and III presented high values related to airway space blockage, posterior rotation of the skull in relation to cervical spine, nasopharyngeal-cervical tracing with normal values and positive hyoid triangle, indicating normality for the majority of individuals. 


\section{Resumo}

A postura do crânio sobre a coluna é um importante fator para o diagnóstico das desordens craniomandibulares funcionais tanto em crianças quanto em adultos. Alterações na biomecânica podem se evidenciadas em exames radiográficos convencionais. O objetivo neste estudo foi relacionar os achados da análise crânio-cervical com os padrões esqueléticos classe I, II e III em indivíduos com idade entre 7 e 12 anos. Radiografias de 92 indivíduos foram realizadas pelo método da postura natural da cabeça e digitalizadas para a análise computadorizada do padrão esquelético e análise cefalométrica crânio-cervical. A análise descritiva foi utilizada com o intuito de relacionar os valores da análise crânio-cervical com o tipo de padrão esquelético apresentado pelos indivíduos. Para os padrões esqueléticos classe I, II e III a porcentagem de tecido mole da nasofaringe e a quantidade linear de tecido mole da orofaringe estavam acima dos valores normais; o traçado nasofaríngeo-cervical foi normal e o triângulo hioideo positivo para a maioria dos indivíduos. A relação angular entre o crânio e coluna cervical mostrou valores menores do que aqueles considerados normais para os padrões esqueléticos Classe I e II. Pôde-se concluir que a maioria dos indivíduos apresentou altos valores de bloqueio das vias aéreas, rotação posterior do crânio, traçado nasofaríngeo-cervical com valores normais e triângulo hioideo positivo.

\section{Palavras-chave}

Crânio; postura; radiologia; cefalometria.

\section{REFERENCES}

1. Festa F, Tecco S, Dolci M, Ciufolo F, Di Meo S, Filippi $\mathrm{MR}$, et al. Relationship between cervical lordosis and facial morphology in Caucasian women with skeletal class II malocclusion: a cross sectional study. J Craniomandibular Pract. 2003;21(2):121-9.

2. Milani RS, DePeriere DD, Lapeyre L, Pourreyhon L. Relationship between dental occlusion and posture. J Craniomandibular Pract. 2000;18(2):127-34.

3. Chaves TC, Silva TSA, Monteiro SAC, Watanabe PCA, Oliveira AS, Grossi DB. Craniocervical posture and hyoid bone position in children with mild and moderate asthma and mouth breathing. Int J Pediatr Otorhinolaryngol. 2010;74(9):1021-27.

4. Rocabado M. Analisis biomacanico craneo cervical a traves de una teleradiografia lateral. Rev Chil Orthod. 1984;1(1):42-52.

5. Huggare J. Postural disorders and dentofacial morphology. Acta Odontol Scand. 1998;56(6):383-86.

6. Rocabado M, Tapia V. Radiographic study of the craniocervical relation in patients under orthodontic treatment and the incidence of related symptoms. J Craniomand Pract. 1987;5(1):12-7.

7. Solow B, Sonnesen L. Head posture and malocclusions. Eur J Orthod. 1998;20(6):685-93.

8. Mays KA, Palmer JB, Kuhlemeier KV. Influence of craniofacial morphology on hyoid movement: a preliminary correlation study. Dysphagia. 2009;24(1):71-6.

9. Rocabado M, Johnson BE, Blakney MG. Physical therapy and dentistry: an overview. J Craniomandibular Pract. 1982;1(1):46-9.

10. Baydas B, Yavuz I, Durma N, Ceylan I. An investigation of cervicovertebral morphology in different sagittal skeletal growth patterns. Eur J Orthod. 2004;26(1):43-9.

11. Fuentes R, Henríquez J, Sandoval P, Matamala F. Estudio anátomo-radiológico de la región craneocervcial em 60 es- tudiantes de la Universidad de La Frontera. Rev Med Chil. 1996;124(12):1483-8.

12. Henríquez J, Fuentes R, Sandoval P, Muñoz A. Análisis de la estabilidad ortostática cráneocervical em adultos jóvenes mapuches. Int J Morphol. 2003;21(2):149-53.

13. Sandoval P, Henríquez J, Fuentes R, Cabezas G, Roldán R. Curvatura cervical. Estúdio cefalométrico en posición de reposo clínico postural. Rev Med Chil. 1999;127(5):54755 .

14. Ferrario VF, Sforza C, Germano D, Dalloca LL, Miani A. Head posture and cephalometric analyses: na integrated photographic/radiographic technique. Am J Orthod Dentofacial Orthop. 1994;106(3):257-66.

15. Gadotti IC, Bérzin F, Biasotto-Gonzalez D. Preliminary rapport on head posture and muscle activity in subjects with class I and II. J Oral Rehabil. 2005;32(11):794-9.

16. Muto T, Kanazawa M. Positional change of the hyoid bone at maximal mouth opening. Oral Surg Oral Med Oral Pathol. 1994;77(5):451-5.

17. Gale A, Kilpeläinen PVJ, Laine-Alava M. Hyoid bone position after surgical mandibular advancement. Eur J Orthod. 2001;23(6):695-701.

18. Perry JL, Bae Y, Kuehn DP. Effect of posture on deglutitive biomechanics in healthy individuals. Dysphagia. 2012;27(1):70-80.

19. Eggensperger N, Smolka W, Iizuka T. Long-term changes of hyoid position and pharyngeal airway size following mandibular setback by sagittal split ramus osteotomy. J Craniomaxillofac Surg. 2005;33(2):111-7.

20. Cuccia AM, Lotti M, Caradonna D. Oral breathing and head posture. Angle Orthod. 2008;78(1):77-82.

21. Wang Q, Jia P, Anderson NK, Wang L, Lin J. Changes of pharyngeal airway size and hyoid bone position following orthodontic treatment of class I bimaxillary protrusion. Angle Orthod. 2012;82(1):115-21.

22. Allhaija ESA, Al-Khateeb SN. Uvulo-glosso-pharyngeal dimensions in different anteroposterior skeletal patterns. Angle Orthod. 2005;75(6):1012-8. 
23. Kerr WJS. The nasopharynx, face height, and overbite.

Received: 30/11/2011 Angle Orthod. 1985;55(1):31-6.

Accepted: 11/05/2012

24. Yamaoka M, Furusawa K, Uematsu T, Okafuji N, Kayamoto D, Kurihara S. Relationship of the hyoid bone and posterior surface of the tongue in prognathism and micro-

Corresponding author gnathia. J Oral Rehabil. 2003;30(9):914-20.

25. Battagel JM, Johal A, L'Estrange PR, Croft CB, Kotecha B. Changes in airway and hyoid position in response to mandibular protrusion in subjects with obstructive sleep apnoea (OSA). Eur J Orthod. 1999;21(4):363-76.

Luciano Pereira Rosa Rua Rio de Contas, 58. Quadra 17. Lote 58. Candeias. Vitória da Conquista-BA CEP.: 45029-094. lucanato@ufba.br 